\title{
PERMAINAN TRADISIONAL MBOJO-BIMA TUTU KALI KU MA..MA.. UNTUK MENSTIMULASI KETRAMPILAN SOSIAL ANAK USIA DINI
}

\author{
Masita, M.Pd.I $I^{1}$ \\ Institut Agama Islam Muhammadiyah Bima \\ Email: ssitasita321@gmail.com
}

Abstract:

This article is titled: Traditional Games of Tutu Kali Ku ma..ma .. To Stimulate Early Childhood Social Skill in Mboj-Bima, with the aim being to get the traditional Mbojo-Bima Tutu Kali game ma ma ... ma ... to stimulate skills social early childhood.

The form of the traditional game Mbojo-Bima Tutu Kali Ku ma..ma ... is it

My tutu is ma ... ma ...

Sa anggonggo wa'i le le..leu .....

La Jami mpako ka dui ma mpeke

I want to go to the gopa cave ina na'e gepu .....

Wio wao salaja wao

Kido, salaja kodo

I asked you to go gopa ina nae gepu

Then the palms are arranged then the group leader chooses to take the hands to be pinched or ears while being lifted up to the height of the height so that it will hurt so much by saying the words:

Waura do you know ...

Then answered: wauraa .......

Ngaha kai uta au ??????????

Ngaha Kai Uta Karamba

Then once the group leader asked by pinching harder

Ngaha ka uta au ???????????

Ngaha kai uta kahoro ma roci hori

After that the group leader quickly removes his hand that picks his hand or ear is up to what is chosen by the leader of the game group.

After that the game is done, which is hiding in places that are considered not easy for the game keeper to know, saying:

\footnotetext{
${ }^{1}$ Masita. Penulis merupakan staf pengajar pada Institut Agama Islam Muhammadiyah Bima
} 
Wauraa ...... ?????
Waura ....... ?????
Waura .......?????
Waura .......?????

Then answered: Wauraa

Then the leader of the game group sees it and says:

Akaku waura eda know re

Then that's all that is done until the game is finished and you get who will be punished. The punishment was whether it was pinched, hit by the palm of his hand. Then finished my tutu times ... bro ...

Traditional children's games are born of culture. the game is a heritage, inheritance from our ancestors. So that by preserving it as the culture of our ancestors. But inheritance itself always changes according to the times and the development of culture.

The relevance of the traditional game of Mojo-Bima Tutu My time is ma..ma ... to stimulate the skills of early childhood is my tutu game ma ... ma ... has a strong relationship with the growth and development of early childhood especially. With these games, it will help stimulate early childhood. So that the horizons of thinking become very broad, advanced and creative and most importantly the children will feel happy, happy and happy without any burden as a child. Children will be more open to playing with their friends and will increase intimacy between one child and another. Especially if the child has returned to their home, the social relations of the community with their friends are not interrupted. Usually children will always remember what they did when at kindergarten school together with their friends, then if their house is close together the children will come to their friend's house to play again, repeating the game that has been done at the school. So that his social relations are not only with his peers but with his friends 'brothers, his friends' siblings, his friends 'parents, and also his friends' neighbors. So that social relations have been nurtured and fostered starting from this early age. When they go up to children, adolescents and adults, the lessons and experiences that they have passed through as children will affect their lives later.

Keywords: Traditional Games My times Tutu ...kali ku ma...ma ..., stimulating and skill Early Childhood Social

\section{PENDAHULUAN}

Jika kita mengatakan kepada anak dengan kata permainan makan sontak saja anak-anak akan merasa senang, bila dibandingkan dengan kita mengatakan mari kita belajar, maka yang terbayang di mimik wajah

Jurnal Pelang̉i Jurnal pemikiran dan penelitian pendidkan Islam anak Usia Dini 
anak adalah rasa tidak mau, malas, bosan, capek dan menjenuhkan.

Permainan tradisional merupakan kekayaan khasanah budaya lokal, yang seharusnya dapat dimanfaatkan dalam pembelajaran jasmani. Jika dihitung mungkin terdapat lebih dari ribuan jenis permainan yang berkembang di negara kita, yang merupakan hasil pemikiran, kreativitas, prakarsa coba-coba, termasuk hasil olah budi para pendahulu kita, yng jika didokumentasikan akan sangat mencengangkan kita. Pertanyaannya, kemanakah semua jenis permainan tradisional tersebut? Ketika anakanak kita tengah gencar-gencarnya diserbu oleh permainan modern melalui tayangan televisi, justru permainan tradisional dalam pelajaran pendidikan jasmani di sekolah dewasa ini sudah tidak dikenal dan tidak diperkenalkan lagi oleh para guru penjas. ${ }^{2}$

Permainan tradisional adalah bentuk kegiatan permainan dan atau olahraga yang berkembang dari suatu kebiasaan masyarakat tertentu. Pada perkembangan selanjutnya permainan tradisional sering dijadikan sebagai jenis permainan yang memiliki ciri kedaerahan asli serta disesuaikan dengan tradisi budaya setempat. Kegiatannya dilakukan baik secara rutin maupun sekali-kali dengan maksud untuk mencari hiburan dan mengisi waktu luang setelah terlepas dari aktiitas rutin seperti bekerja mencari nafkah, sekolah, dan sebagainya.

Dalam pelaksanaannya permainan tradisional dapat memasukkan unsur-unsur permanan rakyat dan permainan anak ke dalamnya. Bahkan mungkin juga dengan memasukkan kgiatan yang mengandung unsur seni seperti yang lajim disebut sebagai seni tradisional. Persoalannya adalah, modul ini mencoba menyajikan permainan tradisional untuk maksud pembelajaran dalam pendidikan jasmani. Sehingga perlu kita bersepakat bahwa apa yang dimaksud dengan permainan tradisional disini bisa identik dengan istilah lain yang juga lajim digunakan, yaitu olahraga tradisional.

Agar suatu kegiatan dapat dikategorikan sebagai permainan tradisional tentunya harus teridentifikasi unsur tradisinya yang memiliki kaitan erat dengan kebiasaan atau adat suatu kelompok masyarakat tertentu. Di samping itu, kegiatan itupun harus kuat mengandung unsur fisik yang nyata-nyata melibatkan kelompok otot besar dan juga mengandung

${ }^{2}$ Permainan Anak dan Aktivitas Ritmik. Modul 4. Hal. 1

Vol. 1, Nomor 1, Maret 2019 
unsur bermain yang melandasi maksud dan tujuan dari kegiatan itu. Maksudnya, suatu kegiatan dikatakan permainan tradisional jika kegiatan itu masih diakui memiliki ciri tradisi tertentu, melibatkan otot-otot besar dan hadirnya strategi serta dasarnya tidak sungguhsungguh terlihat seperti apa yang ditampilkannya. Olahraga tradisional pada dasarnya dapat digolongkan ke dalam beberapa jenis, yang secara umum menggambarkan karakteristik dari cara pelaksanaannya. Pada pengelompokkan pertama, kita dapat membedakan olahraga tradisional dari pekat tidaknya unsur tradisi yang melekat pada olahraga tersebut, sehingga dapat dibedakan antara sangat pekat unsur tradisi dan unsur seninya seperti pencak silat dan bejang.

Jadi perbedaan esensi permainan tradisional dari aktivitas tradisi lainnya dapat dilihat dari banyak tidaknya gerak yang dilibatkan. Jenis permainan tradisional yang banyak mengandung gerak fisik seperti permainan gobak sodor, permainan hadang, permainan bebentengan, dan sebagainya. Ada juga jenis olahraga tradisional yang kandungan gerak fisiknya sangat minim tetapi kaya akan nilai-nilai seni seperti nyanyian dan doa-doa sakral. Adapun yang akan disajikan dalam permainan tradisional ini tentu dari jenis yang permainan pertama, yang kandungan unsur aktivitas fisiknya sangat pekat. ${ }^{3}$

Begitupula anak usia dini, sejak dini seorang anak harus berani dan mampu menghadapi perbedaan dalam kehidupan sosial ini. Modal anak untuk mengatasi perbedaan ini adalah kemampuan social life skill. ${ }^{4}$ Social life skill sebagai bagian dari life skill merupakan modal dasar untuk berinteraksi. Kemampuan untuk bekerjasama dengan penuh pengertian, rasa empati, dan kemampuan berkomunikasi dua arah merupakan bagian dari social life skill sangat dibutuhkan oleh seseorang dalam menjalin hubungan yang harmonis.

Anak sejak usia dini dituntut untuk mempunyai kemampuan social life skill agar dapat berdampingan dengan orang lain dan lingkungan sekitar. Anak dengan social life skill dapat belajar untuk menghargai perbedaan antara individu sehingga tidak memicu situasi yang tidak di-

${ }^{3} \mathrm{Ibid}$, hal 3

${ }^{4}$ Ni Nyoman Seriati dan Nur Hayati, Permainan Tradisional Jawa Gerak dan Lagu Untuk Menstimulasi Ketrampilan Sosial Anak Usia Dini. Artikel. Pendidkan Seni Tari PGPAUD, Hal. 1, Dikutip dari: Lawhon, 2000

Jurnal Pelangỉ Jurnal pemikiran dan penelitian pendidkan Islam anak Usia Dini 
inginkan.

Ketrampilan sosial tidak terbentuk secara tiba-tiba, namun merupakan imitasi dan pembiasaan dari lingkungan terdekat anak, sehingga anak tidak memahami konteks sosial yang dihadapinya dan tidak terbiasa menggunakan cara-cara yang diterima secara sosial.

Di sisi lain, pola permainan anak mulai bergeser pada pola permaian di dalam rumah. Beberapa bentuk permaianan yang banyak dilakukan adalah menonton tayangan televisi dan permainan lewat games station dan komputer. Permaianan yang dilakukan di dalam rumah lebih bersifat individual. Permainan - permaian tersebut tidak mengembangkan ketrampilan sosial anak. Anak bisa pandai dan cerdas namun secara sosial kurang terasah. Hasil penelitian Izzaty terhadap 35 Taman Kanak-Kanak di Yogyakarta tahun 2008 berkenaan dengan pemecahan masalah sosial anak menyimpulkan bahwa stategi penyelesaian permasalahan pada saat anak berinteraksi cenderung negatif atau bersifat agresi, seperti memukul, menendang, menjambak, dan mencubit.

Hasil penelitian tersebut menunjukkan bahwa anak-anak yang memiliki cara agresif dalam memecahkan masalahnya, ternyata pada usia 23 tahun perilaku ini masih terlihat kuat. Sebaliknya, anak-anak yang cederung malu-malu atau inhibisi (inhibited) juga terlihat kuat pada usia 23 tahun. Ayriza, Izzaty, dan Setiawati, menemukan bahwa pemahaman pendidik Taman Kanak-Kanak dalam kajian ketrampilan sosial sangat minim dan beberapa bentuk program yang ada dilakukan dengan tidak sadar atau terprogram dengan jelas. ${ }^{5}$ Kegiatan pembelajaran yang tidak terprogram akan berakibat pada kurang efektifnya pelaksanaan kegiatan atau pembelajaran tersebut, dan akan membawa hasil yang kurang maksimal.

Beranjak dari penjelasan dan fenomena di atas, penanaman ketrampilan sosial pada anak suai dini semakin melemah dan perlu kembali diperhatikan dan dilakukan lewat permainan-permaian anak. Peningkatan dalam perilaku dapat ditingkatkan pula melalui aktivitas kegiatan lewat pembelajaran di Taman Kanak-Kanak atau play group, kegiatan di pos PAUD maupun permaianan di rumah bersama teman atau tetangga. Untuk itu bentuk-bentuk permaianan yang mengem-

${ }^{5}$ Ibid, hal 2, Dikutip dari: Ayrizi, Izzaty dan Setiawati, 2004

Vol. 1, Nomor 1, Maret 2019 
bangkan ketrampilan sosial anak perlu diidentifikasi dan dikembangkan. Hasil identifikasi dan pengembangan berbagai bentuk permaian ini selanjutnya dapat digunakan untuk membantu pendidik dalam memberikan stimulasi yang mendidik pada anak usia dini.

Pembelajaran anak usia dini dilakukan dengan metode bermain. Bermain pada hakekatnya merupakan kegiatan yang menyenangkan. Kegiatan bermain ini senantiasa dilakukan anak setiap saat. Pada masa sekarang, kegiatan bermaian anak cenderung dilakukan di dalam rumah. Hal ini berbeda dengan permaianan pada masa lalu atau permainan tradisional. Anak-anak pada masa lalu sangat senang bermain di luar bersama teman-temannya. Berjam-jam anak sangat betah bermain di luar rumah, karena permaiananya banyak berinteraksi dengan orang lain. Permaian tradisional ini cenderung mengembangkan ketrampilan sosial anak. Hasil penelitian yang dilakukan Seriati, dkk, menunjukkan bahwa permainan tradisional yang terdiri dari permainan gerak serta permainan gerak dan lagu sangat berpotensi mengembangkan ketrampilan sosial anak. $^{6}$

Mbojo -Bima merupakan merupakan salah satu kota madya setelah otonomi daerah tahun 2005 menjadi kota Bima berada di ujung timur kota Bima. Kota kecil nan asri dan indah yang dikelilingi oleh gunung dan ditengah-tengah adalah kota Bima. Kota Bima merupakan salah satu kota yang sangat nyaman, aman, damai dan indah. Kota yang salah satu disebutkan dalam Al-Qur'an surah Al-Baqaroh (2) ayat 233 yakni "bima ta'malun nabasyir"

Masyarakat Mbojo-Bima memiliki beberapa macam permainan tradisional salah satunya yang paling diminati oleh anak-anak adalah tutu kali ku ma..ma... Permainan tutu kali ku ma..ma.. sendiri memiliki keunikan dan kekhasan tersendiri. Permainan Tutu kali ku ma..ma..., adalah salah satu model permainan tradisional Mbojo-Bima yang sangat terkenal. Anak-anak asli dou Mbojo (Orang Bima) selalu tahu dan melakukan kegiatan permainan yang sangat menyenangkan ini. Sewaktu kecil anak-anak dou Mbojo (Orang Bima) selalu memainkan permainan ini dengan sangat menyenangkan. Permainan ini adalah permainan dengan sepuluh orang anak atau bisa kurang dan bisa juga lebih dari sepuluh

${ }^{6}$ Ibid, hal 3, Dikutip dari: Seriati, 2010

Jurnal Pelang̉i Jurnal pemikiran dan penelitian pendidkan Islam anak Usia Dini 
lalu duduk melingkar lalu mengulurkan tangan dan membuka telapak tangan mereka. Permainan ini permainan kolektif, lalu ketua atau pimpinan kelompok bermain lalu memulai bermain permainan dengan menghitung permainan tutu kali ku ma..ma...ke telapak tangan temantemannya tadi hingga diakhir lagu tutu kali ku ma...ma... di tangan temantemannya, semacam undian namun bentuknya menggunakan tangan yang ditunjuk ke arah telapak tangan teman-temannya. Sambil terus bermain menunjuk ke tangan teman-temannya yang bermain sambil menyanyikan lagu:

Tutu kali ku ma...ma.......

Sa anggonggo wa'i le le..leu.....

La Jami mpako ka dui ma mpeke

Ka pela sara goa gopa ina na'e gepu.....

Wio wao salaja wao

Kido kado salaja kodo

Ka pela sara ngoa gopa ina nae gepu

Lalu telapak tangan disusun kemudian ketua kelompok memilih mengambil tangan untuk dicubit atau kuping sambil diangkat keatas setinggi tingginya sehingga akan sakit sekali dengan mengatakan kata-kata:

Waura ngahamu....

Lalu dijawab: wauraa.......

Ngaha kai uta au?????????

Ngaha kai uta karamba

Lalu sekali lai ketua kelompok bertanya dengan mencubit lebih keras

Ngaha ka uta au???????????

Ngaha kai uta kahoro ma roci hori

Setelah itu ketua kelompok dengan cepat melepas tangannya yang mencupit tangan atau kuping terserah yang dipilih oleh ketua kelompok permainan tersebut.

Setelah itu dilakukan permainan yakni bersembunyi di tempat-tempat yang dianggap tidak mudah diketahui oleh penjaga permainan tadi, dengan mengatakan:

Wauraa......?????

Waura........????

Waura.......???? 
Waura......?????

Lalu dijawab: Wauraa

Lalu dilihatlah oleh ketua kelompok permainan dan mengatakan:

Akaku waura eda mba nahu re

Lalu itu aja yang dilakukan hingga selesai permainan dan didapatlan siapa yang akan dihukum. Hukumannya adalah apakah itu dicubit, dipukul telapak tangannya. Maka selesailah sudah permainan tutu kali ku ma..ma.. ${ }^{7}$

Dan menghitung satu persatu ditangan temannya makan ketika diakhir ditangan siapa yang berakhirnya hitungan itu maka dialah yang keluar. Lalu dilakukan langkah yang sama lagi hingga tersisa 1 orang. Maka 1 orang inilah yang nantinya akan dihukum untuk menemukan teman-temannya. Semua teman-temannya tadi yang bermain akan pergi bersembunyi di kolom-kolom uma haju (rumah kayu) masyarakat MbojoBima, lalu aka raba (di pagar) yang dari bambu, lalu aka kuta (atau di pagar bisa dari bambu bisa juga pagar dari kayu), lalu ese uma (diatas rumah kayu), lalu ade wombo (di kolom rumah kayu), lalu aka riha (di dapur rumah kayu), dan ditempat lain-lainnya. Jika ditemukan oleh temannya yang menjalani hukuman tadi maka dia akan bilang aka re waura ede ma nahu (itu sudah saya temukan kamu), maka dia akan diganti lagi untuk menjalani hukuman yang sama hingga permainan berakhir atau selesai dan mereka merasa puas akan nyaman, gembira dan bahagia. Tetapi untuk anak Anak Usia Dini tidak dimainkan di uma haju (rumah kayu) melainkan dimainkan di sekolah saja, yakni mereka akan melakukan di halaman sekolah dan ketika permainan tersebut dimainkan maka anakanak akan cili (bersembunyi) ketika permainan berlangsung di wombo meja (kolom meja), lalu di wombo mbunga (dibawah pohon bunga), lalu di kontu ncai kelas (di belakang pintu kelas), di wombo bangko (di kolom bangku), di kontu fu'u haju (di belakang pohon), di kontu ibu guru (di belakang tubuh ibu guru), dan lain-lainnya, sehingga diakhir permainan mereka semua gembira dan bahagia.

Ketrampilan sosial merupakan salah satu aspek perkembangan anak usia dini yang sangat penting dalam menentukan keberhasilan anak untuk memulai dan memiliki hubungan sosial dengan orang lain. Ketrampilan

${ }^{7}$ Syair lagu Bima: Tutu kali ku ma..ma.. , Yang diakses dari: http://ompundaru.wordpress. com/2008/11/28

Jurnal Pelangi Jurnal pemikiran dan penelitian pendidkan Islam anak Usia Dini 
sosial merupakan bentuk dari perilaku, perbuatan dan sikap yang ditampilkan oleh individu ketikan berinteraksi dengan orang lain yang dilakukan dengan tepat sehingga dapat memberian rasa nyaman bagi orang yang berada di sekitarnya. Anak yang menguasai ketrampilan sosial dengan baik diharapkan dapat menyesuaikan diri dengan norma kelompok sehingga dapat berinteraksi secara baik dan dapat diterima di lingkungan sekitar anak.

Keinginan kuat untuk dapat diterima dalam lingkungan teman adalah kebutuhan yang diperlukan anak, sehingga anak akan berusaha menguasai ketrampilan sosial yang dibutuhkan untuk dapat bergabung pada kelompok sosialnya. Anak akan belajar berteman, menghargai orang lain, belajar bekerjasama, memberi dan menerima, serta mampu menghargai kekurangan orang lain. Lingkungan yang baik akan mengajarkan hal-hal yang positif juga untuk anak. Anak akan mendapatkan pelajaran moral yang baik dari orang-orang yang ada di sekitar anak, karena sifat dasar anak adalah meniru. ${ }^{8}$

Pendidikan anak usia dini sering kita mendengar orang menyebutnya dengan PAUD. Anak usia dini merupakan anak pada masa pertumbuhan dan perkembangan yang sangat menentukan. Menurut Anderson, menyampaikan bahwa anak usia dini adalah anak yang berada di periode tahun awal hidup yang memerlukan kesempatan yang cukup untuk pertumbuhan dan mencegah bahaya kerentanan. ${ }^{9}$ Anak berkembang dibentuk oleh sumber ketahanan serta kerentanan. Pengalaman kumulatif anak merupakan penentu dari perkembangan. Peluang perkembangan anak usia dini digunakan untuk membangun landasan penting bagi kesuksesan akademik, kesehatan, dan kesejahteraan umum. Pendidikan anak usia Dini (PAUD) menurut UU No 20 Tahun 2003 tentang Sistem Pendidikan Nasional adalah suatu upaya pembinaan yang ditujukan kepada anak sejak lahir sampai dengan usia enam tahun yang dilakukan melalui pemberian rangsangan pendidikan untuk membantu pertumbuhan dan perkembangan jasmani dan rohani agak anak memiliki kesiapan dalam memasuki pendidikan lebih lanjut. Sehingga PAUD me-

${ }^{8}$ Aulio Rohmawati. Stimulasi Ketrampilan sosial anak Ditinjau Dari Satuan Pendidikan Anak Usia Dini. Skripsi. Program Studi Pendidikan Guru Pendidikan Anak Usia Dini, Fakultas Ilmu Pendidikan, Universitas Negeri Semarang, 2016, hal 19-20

${ }^{9} \mathrm{Ibid}$, hal 4-5, Dikutip dari: Anderson, et.al. 2003: 32 
rupakan lembaga yang melayani kebutuhan tumbuh kembang anak usia dini sehingga mampu melalui tingkat perkembangannya dengan baik. ${ }^{10}$

\section{B. PERMAINAN TRADISIONAL DI INDONESIA}

\section{(a). Konsep Permaian}

Menurut Hans Daeng permainan adalah bagian mutlak dari kehidupan anak dan permainan merupakan bagian integral dari proses pembentukan kepribadian anak. ${ }^{11}$ Andang Ismail menuturkan bahwa permainan memiliki dua pengertian. Pertama, permainan adalah sebuah aktivitas bermain yang murni mencari kesenangan tanpa mencari menang atau kalah. Kedua, permaianan diartikan sebagai aktivitas bermain yang dilakukan dalam rangka mencari kesenangan dan kepuasan, namun ditandai pencarian menang-kalah. ${ }^{12}$ Permainan memiliki sifat sebagai berikut:

1) Permainan di motivasi secara personal, karena memberi rasa kepuasaan,

2) Permainan lebih asyik dengan aktivitas permainan (sifatnya spontan) daripada tujuannya,

3) Aktivitas permainan dapat bersifat nonliteral,

4) Permainan bersifat bebas dari aturan-aturan yang dipaksakan dari luar, dan aturan-aturan yang ada dapat dimotivasi oleh para pemainnya,

5) Permainan memerlukan keterlibatan aktif dari pihak pemainnya.

Jadi yang dimaksud dengan permainan adalah suatu aktivitas yang dilakukan oleh beberapa anak untuk mencari kesenangan yang dapat membentuk proses kepribadian anak dan membantu anak mencapai perkembangan fisik, intelektual, sosial, moral, dan emosional. ${ }^{13}$

\section{(b). Hakekat bermain dan Permainan}

Menurut Hurlock, masa usia 3-5 tahun merupakan masa permainan. ${ }^{14}$

\footnotetext{
${ }^{10} \mathrm{Ibid}$, hal 4-5

${ }^{11}$ Konsep Permainan. Hal 1, Dikutip dari: Hans Daeng, 2009: 17

${ }^{12}$ Ibid, hal 1, Dikutip dari: Andang Ismail, 2009: 26

${ }^{13}$ Ibid, hal 1

${ }^{14} \mathrm{Ni}$ Nyoman Seriati dan Nur Hayati, Permainan Tradisional Jawa Gerak dan Lagu Untuk Menstimulasi
}

Jurnal Pelangi Jurnal pemikiran dan penelitian pendidkan Islam anak Usia Dini 
Bermain sebagai kegiatan yang mempunyai nilai praktis, artinya bermain digunakan sebagai media untuk meningkatkan keterampilan dan kemampuan tertentu pada anak ini menurut Plato dan kawan-kawan. ${ }^{15}$ Bermain pada hakekatnya merupakan suatu kegiatan yang memiliki karakteristik aktif dan menyenangkan. Bermain juga dilakukan secara suka rela atau volunter dan biasanya muncul dari motivasi internal.Kegiatan bermain biasanya bersifat simbolik atau pura-pura karena tidak terjadi secara nyata.Bermain memiliki arti yang penting bagi anak, meskipun kegiatan bermain ini tidak terjadi nyata.

Mainan mempunyai manfaat anatara lain untuk:

a) mengoptimalkan perkembangan fisik dan mental anak:

b) memenuhi kebutuhan emosi anak:

c) sosialisasi anak.Bermain juga berfungsi untuk mengembangkan aspeka perkembangan anak antara lain mngembangkan kemampuan motorik,kognitif,afektif,bahasa serta aspek sosial. ${ }^{16}$

\section{(c). Klasifikasi Bermain}

Menurut Mildred Parten, dilihat dari perkembangan sosial, bermain dapat dikelompokkan menjadi lima macam:

(1). Solitary games (bermain sendiri).

(2). Onlooker games (bermain dengan melihat temannya bermain).

(3). Parallel games (bermain paralel dengan temannya), bermain dengan materi yang sama, tetapi masing-masing bekerja sendiri.

(4). Associative games (bermain beramain-ramain), anak bermain bersama-sama tanpa ada suatu organisasi.

(5). Cooperative games (bermain kooperatif), ada aturan dan pembagian peran, salah satu anak menolak bermain, permaianan tidak akan terlaksana.

Permainan juga dapat dikelompokkan dalam: (1). Permaian fisik, (2). Lagu anak-anak, (3). Teka-teki, berpikir logis/matematis, (4). Bemaian dengan benda-benda, dan (5). Bermain peran. ${ }^{17}$

Ketrampilan Sosial Anak Usia Dini. Artikel. Pendidkan Seni Tari PGPAUD, HAL. 1, Dikutip dari: Sujiono, 2005

${ }^{15}$ Ibid, hal 3, Dikutip dari: Plato, dkk, dalam Sujiono, 2005

${ }^{16}$ Ibid, hal 3, Dikutip dari: Suyanto, 2005

${ }^{17}$ Ibid, hal 4 


\section{(d). Ketrampilan Sosial}

\section{1). Pengertian Ketrampilan Sosial}

Curtis menyatakan bahwa ketrampilan sosial merupakan strategi yang digunakan ketika orang berusaha memulai ataupun mempertahankan suatu interaksi sosial. ${ }^{18}$ Kelly menyatakan bahwa ketrampilan sosial adalah yang diperoleh individu melalui proses belajar yang digunakan dalam berhubungan dengan lingkungannya dengan cara baik dan tepat. ${ }^{19}$ Hal ini bertujuan untuk mendapatkan pengukuh dari hubungan interpersonal yang dilakukan dan menolak hadirnya suatu keadaan yang tidak menyenangkan. Ketrampilan sosial menurut Morgan dalam Cartledge dan Milburn adalah kemampuan untuk menyatakan dan berinteraksi secara positif dengan orang lain..$^{20}$ Dari beberapa batasan yang dikemukakkan ini, dapat disimpulkan bahwa ketrampilan sosial adalah ketrampilan atau strategi yang digunakan untuk memulai ataupun mempertahankan suatu hubungan yang positif dalam interaksi sosial, yang diperoleh melalui proses belajar bertujuan untuk mendapatkan hadiah atau penguat dalam hubungan interpersonal yang dilakukan. $^{21}$

\section{2). Aspek Ketrampilan Sosial}

Hasil penelitian yang dilakukan oleh Pusat Studi Pendidikan Anak Usia Dini Universitas Negeri Yogyakarta tahun 2004, didapatkan hasil bahwa ada tiga aspek utama dalam ketrampilan sosial yang perlu ditanamkan dari sejak usia dini, yaitu:

1). Empati, meliputi:
a) Penuh pengertian,
b) Tenggang rasa, dan
c) Kepedulian pada sesama,

2) Afiliasi dan resolusi konflik, meliputi:

a) Komunikasi dua arah/hubungan antar pribadi,

b) kerjasama, dan

c) Penyelesaian konflik,

\footnotetext{
${ }^{18}$ Ibid, hal 4, Dikutip dari: Curtis, 1988

${ }^{19}$ Ibid, hal 4, Dikutip dari: Kelly dalam Ramdhani, 1991

${ }^{20} \mathrm{Ibid}$, hal 4, Dikutip dari: Morgan dalam Cartledge dan Milburn, 1995

${ }^{21} \mathrm{Ibid}$, hal 4
} 
3) Mengembangkan kebiasaan positif, meliputi:

a) tata krama/kesopanan,

b) Kemandirian, dan

c) Tanggung jawab sosial.

Ketiga aspek diatas mengacu kepada pendapat Curtis, Brewer, dan Depdiknas bahwa aspek ketrampilan sosial yang dapat ditanamkan pada anak usia dini antara lain: empati, tenggang rasa, kepedulian dengan sesama, kerjasama, penyelesaian konflik, kemandirian dan tanggung jawab sosial. $^{22}$

\section{(e). Permainan Tradisional di Indonesia}

\section{1). Permaianan Tradisional}

Permaianan tradisional sering disebut juga permaianan rakyat, merupakan permaian yang tumbuh dan berkembang pada masa lalu terutama tumbuh di masyarakat pedesaan. Permaian tradisional tumbuh dan berkembang berdasar kebutuhan masyarakat setempat. ${ }^{23}$ Kebanyakan permaianan tradisional dipengaruhi oleh alam lingkungannya, oleh karena permaian ini selalu menarik, menghibur sesuai dengan kondisi masyarakat saat itu. Permaianan tradisional menurut Yunus, umumnya bersifat rekreatif, karena banyak memerlukan kreasi anak. ${ }^{24}$ Permaian ini biasanya merekonstruksi berebagai kegiatan sosial dalam masyarakat. Seperti: pasaran yang menirukan kegiatan jual beli, jaranan yang menirukan orang yang sedang melakukan perjalanan dengan naik kuda, permaian menthok-menthok yang melambangkan kemalasan.

Permaian tradisional mendapat pengaruh yang kuat dari budaya setempat, oleh karena itu permaian tradisional mengalami perubahan baik berupa pergantian, penambahan maupun pengurangan sesuai dengan kondisi daerah setempat. Dengan demikian, permaian tradisional meskipun nama permaiannya berbeda antar daerah, namun memiliki persamaan atau kemiripan dalam cara memainkannya. ${ }^{25}$

Permainan tradisional menurut Ernawati, adalah segala bentuk per-

\footnotetext{
${ }^{22}$ Ibid, hal 5, Dikutip dari: Curtis, 1988, Brewer 2007, dan Depdiknas 2002.

${ }^{23}$ Ibid, hal 5, Dikutip dari: Yunus, 1981

${ }^{24}$ Ibid, hal 5, Dikutip dari: Yunus, 1981

${ }^{25} \mathrm{Ibid}$, hal 5
} 
mainan yang sudah ada sejak jaman dahulu dan diwariskan secara turun temurun dari generasi ke generasi. ${ }^{26}$ Permainan tradisional sebagian besar berupa permaian anak yang merupakan bagian dari Folklore. Permainan tradisional adalah suatu hasil budaya masyarakat, yang berasal dari zaman yang sangat tua, yang telah tumbuh dan hidup hingga sekarang, dengan masyarakat pendukungnya yang terdiri atas tua muda, laki perempuan, kaya miskin, rakyat bangsawan dengan tiada bedanya. Permainan tradisional bukanlah hanya sekedar alat penghibur hati, sekedar penyedar pikiran atau sekedar saranan berolahraga tetapi memiliki berbagai latar belakang yang bercorak rekreatif, kompetitif, paedagogis, magis dan religius. Permainan tradisional juga menjadkan orang bersifat terampil, ulet, cekata, tangkas dan lain sebagainya. Jadi dapat disimpulkan bahwa permaianan tradisional adalah suatu permainan warisan dari nenek moyang yang wajib dan perlu dilestarikan sebagai bagian dari proses perkembangan anak. ${ }^{27}$

Jadi permaian tradisional adalah permainan warisan dari leluhur kita atau nenek moyang kita yang wajib kita jaga, lindungi dan dilestarikan semanjang masa walau jaman ini berubah dan bertambah, karena permainan tradisional menunjukkan jati diri, eksistensi dan kekayaan budaya yang kita miliki yakni budaya khas Mbojo-Bima.

\section{2). Jenis-jenis Permainan Tradisional}

Permainan tradisional memiliki berbagai macam jenis, hal ini dibedakan dari jumlah peserta permainannya. Permainan tradisional setiap daerah pada dasarnya memiliki banyak kesamaan dari cara memainkannya. Menurut Sukirman Dharmamulya, mengatakan bahwa jenisjenis permainan tradisional memiliki beberapa kategorisasi menurut pola permainnnya yaitu:

a. Bermain dan bernyanyi, dan atau dialog,

b. Bermain dan pola pikir

${ }^{26}$ Betty Yulia Wulansari. Pelestarian Seni Budaya dan Permaian Tradisional Melalui Tema Kearifan Lokal Dalam Kurikulum Pendidikan Anak Usia Dini. Jurnal Ilmiah Pendidikan Pra-Sekolah dan Sekolah Awal. Indria. e-ISSN 2524 - 004X JL II (I). Universitas Muhammadiyah Ponorogo, 2017. Hal. 3-4

${ }^{27}$ Ibid, hal. 4, Dikutip dari: Agung Nugroho, 2005

Jurnal Pelang̉i Jurnal pemikiran dan penelitian pendidkan Islam anak Usia Dini 
C. Bermain dan adu ketangkasan. ${ }^{28}$

Berikut definisi berbagai jenis permainan tradisional berdasarkan hasil kategorisasi yang dilakukan oleh Sukirman'29: a. Bermain dan bernyanyi, dan atau dialog.

Permainan anak dengan pola bermain bernyanyi dan atau dengan berdialog dimaksudkan adalah pada waktu permainan itu dimainkan diawali atau diselingi dengan nyanyian, dialog, atau keduanya; nyanyian dan dialog menjadi inti dalam permainan tersebut. Pola permainan anak dengan bernyanyi dan atau dengan dialog pada umumnya dilakukan secara kelompok, dan permainan ini biasanya dimainkan oleh mayoritas anak perempuan. Permainan ini bersifat rekreatif, interaktif, yang mengekspresikan pengenalan tentang lingkungan, hubungan sosial, tebaktebakan, dan sebagainya. Permainan dengan pola bermain dan bernyanyi, dan atau dialog dapat dilihat dalam tabel sebagai berikut:

\begin{tabular}{|l|l|l|l|l|}
\hline No & Jenis Permainan & \multicolumn{1}{|c|}{$\begin{array}{c}\text { Pelaku } \\
\text { Permainan }\end{array}$} & \multicolumn{1}{|c|}{ Permainan } & $\begin{array}{c}\text { Akhir } \\
\text { Permainan }\end{array}$ \\
\hline 1. & Ancak-ancak Alis & $\begin{array}{l}\text { Perempuan/laki- } \\
\text { laki }\end{array}$ & Bernyanyi, dialog & Kalah-Menang \\
\hline 2. & Bethet thing-Thong & $\begin{array}{l}\text { Perempuan/laki- } \\
\text { laki }\end{array}$ & Bernyanyi & Dadi-Mentas \\
\hline 3. & Bibitumbas timun & Perempuan & Bernyanyi, dialog & Tidak ada \\
\hline 4. & Cacah Bencah & Perempuan & Bernyanyi & Dadi-Mentas \\
\hline 5. & $\begin{array}{l}\text { Cublak-cublak } \\
\text { Suweng }\end{array}$ & Perempuan & Bernyanyi & Dadi-Mentas \\
\hline
\end{tabular}

\section{3). Bentuk Permaianan Tradisional di Indonesia}

Indonesia kaya akan seni budaya dan permainan tradisional. Setiap daerah memiliki seni budaya, permaianan tradisional yang beraneka ragam. Mulai dari sabang hingga Merauke. Permaian yang sering dimainkan di jawa seperti engklek, gobak sodor, delikan, nekeran, apolo yang

${ }^{28}$ Gian Prantoro. Pengaruh Penggunaan Permainan Tradisional Bakiak dan Engklek Terhadap Peningkatan Ketrampilan Sosial Anak Usia Dini. Skripsi. Pada Program Studi Teknologi Pendidikan, Jurusan Kurikulum dan Teknologi Pendidikan, Fakultas Ilmu Pendidikan, Universitas Negeri Yogyakarta, 2015, hal. 27, dikutip dari: Sukirman Dharmamulya, 2004: 35

${ }_{29}$ Ibid, hal 27, Dikutip dari Sukirman, hal 2004: 37, 123, 139 
sekarang jarang dijumppai di lingkungan masyarakat. Anak-anak tidak lepas dari namanya permaianan. Salah satu karakteristik anak usia dini adalah bekerja dengan bermaian. ${ }^{30}$

Maka permaianan merupakan hal yang tidak dapat dipisahkan dengan dunia anak. Arus perkembangan permainan berteknologi maju terus mengerus permaian tradisional. Prinsip perkembangan adalah perkembangan merupakan proses yang tidak pernah berhenti (never ending process). Manusia secara terus menerus berkembang atau berubah yang dipengaruhi oleh pengalaman atau belajar sepanjang hidupnya. Prinsip yang lain adalah semua aspek perkembangan saling mempengaruhi, baik aspek fisik, emosi, intelegensi maupun sosial. ${ }^{31}$ Saat ini anak-anak usia dini sudah mengenal gedget. Gedget dipilih sebagai permaian bagi sang anak-anak, karena orang tua mudah mengawasi anak-anak ketika bermain. ${ }^{32}$

Orang tua lebih praktis dan merasa aman daripada anak-anak bermain di luar bersama temannya. Namun sayangnya, hal ini semakin menjauhkan anak-anak dari seni budaya dan permainan tradisional dan menghambat hubungan sosial emosional anak dengan lingkungan sekitar. Dari hal tersebut, untuk menghindari punahnya seni budaya dan permaian tradisional maka diperlukan seni budaya dan pelestarian permainan tradisional. Salah satunya melalui lembaga pendidkan anak usia dini (PAUD). PAUD merupakan lembaga yang tepat memelihara kelangsungan permaian tradisional Indonesia dari gerusan arus teknologi. ${ }^{33}$

Beberapa macam bentuk permainan tradisional Indonesia adalah di Jawa Tengah seperti: Dhelikan, Jawa Timur yakni: singidhan, Bentengan, Sumatera Barat yakni Tonggak Dingin dan Jawa Barat dan Banten yakni: Ucing. Semua permainan diatas tidak alat bantu khusus yang dipakai dan tempat bermainnya di luar atau di dalam ruangan yang luas dan banyak tempat untuk bersembunyi. Jumlah orang yang bermain yakni 2 sampai 5 orang bahka lebih, sedangkan usia antara 2 sampai 6 tahun. Aturan mainnya adalah:

\footnotetext{
${ }^{30} \mathrm{Ibid}$, hal. 2

${ }^{31}$ Ibid, hal 2. Dikutip dari: Kompasiana, 2016.

${ }^{32}$ Ibid, hal 2

${ }^{33} \mathrm{Ibid}$, hal.2
}

Jurnal Pelangi Jurnal pemikiran dan penelitian pendidkan Islam anak Usia Dini 
1) Hitungan yang harus dihitung penjaga adalah 10 hitungan,

2) Pemain yang sudah ketahuan dan disebut namanya harus keluar dari persembunyiannya,

3) Pemain yang ketahuan pertama adalah calon sebagai penjaga pada permaianan selanjutnya, kalau dalam permainan tersebut tidak berbentengan (benteng atau pos jaga terkuasai oleh pemain yang sembunyi),

4) Pemain yang sembunyi dan bisa menguasai benteng atau pos jaga harus meneriakkan benteng dan semua pemain yang bersembunyi harus keluar semua dan pemain diulang kembali dengan penjaga yang sama,

5) Pemain yang sudah ketahuan boleh sembunyi kembali kalau benteng yang dijaga terkuasai oleh pemain lain yang sembunyi,

6) Pemain yang sudah ketahuan, tidak jadi mati kalau dia bisa lebih dahulu menyentuh benteng atau pos jaga dan dia bisa sembunyi lagi.

Cara mainnya adalah

1) Pada tahap persiapan yakni:

(1) Mempersiapkan tempat,

(2) Mempersiapkan pemain,

(3) Membuat atau membagi kelompok, dan

(4) Mengatur posisi pemain, sedangkan pada tahap

2) Pada tahap Pelaksanaan yakni:

(1) Semua pemain melakukan hompimpah,

(2) Satu orang pemain yang kalah akan menutup matanya pada salah satu tempat yang dianggap sebagai benteng, sementara yang lain mncari tempat untuk bersembunyi,

(3) Setelah menghitung sampai jumlah tertentu, maka mulailah pemain yang menutup mata tersebut mencari tiap orang yang bersembunyi,

(4) Bila telah menemukan orang yang bersembunyi, pencari ini harus cepat-cepat berlari ke benteng sambil menyebut nama orang yang ketahuan persembunyiannya. Bila juga dengan anak yang ketahuan,karena bila berhasil lebih dahulu menyentuh benteng, maka pada tahap selanjutnya dia tidak akan jaga. Anak lain yang bersembunyi dapat pula menyentuh benteng agar tidak jaga 
pada tahap selanjutnya, asalkan tidak ketahuan dengan pencari,

(5) Setelah semua telah ketahuan persembunyiannya, maka pncari akan menutup matanya kembali pada benteng dan anak-anak lain membentuk barisan di belakangnya. Pencari akan menyebut salah satu nomor. Anak yang ada di urutan nomor yang disebut akan menjadi pihak yang kalah bila tadi dia tidak berhasil lebih dulu mencapai benteng. Sedangkan bila anak pada urutan yang disebut ternyata adalah anak yang berhasil mencapai benteng lebih dahulu pada saat ketahuan tempat persembunyiannya, maka si pencari tetap dalam posisi kalah dan permainan dilanjutkan.

Pada aspek yang dikembangkan yakni:

1) Moral dan agama yaitu sebagai berikut: moral dan agama anak dapat dirangsang dengan cara membuat aturan bermain seperti: meminta main dan mengucapkan kata tertentu yang menunjukkan rasa syukur jika berhasil menemui anak yang dicari,

2) Fisik, yaitu sebagai berikut: pada saat anak mencari teman lalu berlari ke benteng merupakan rangsangan terhadap fisik anak,

3) Bahasa, yaitu sebagai berikut: komunikasi lisan anak akan terangsang melalui percakapan,

4) Kognitif, yaitu sebagai berikut: mengingat aturan main, mencari tempat persembunyian yang tepat, menemukan teman yang bersembunyi, menyebutkan urutan nomor, dan

5) Sosial -Emosional, yaitu sebagai berikut: mengambil sikap tepat dan menurunkan egosentris diri pada saat hompipah, menerima aturan bermain dengan sportif. ${ }^{34}$

Adapula permainan tradisional dari Jawa Tengah bernama Englek, Jawa Timur bernama Angkle, Sumatera Barat Lore, Jawa Barat dan Banten Sondah, Sulawesi Tengah Nokandende, dan Maluku Gici-Gici. Alat permainan menggunakan:

1) Pecahan Genting/Ubin/asbes/keramik, dan

2) Kapur/arang/ranting untuk membuat gambar. Sedangkan tempat

${ }^{34}$ Heru Subagiyo. Permainan Tradisional Sebagai Media Pembelajaran Anak. Jurnal. Hal. 8-11

Jurnal Pelangi Jurnal pemikiran dan penelitian pendidkan Islam anak Usia Dini 
bermain di luar ruangan atau dalam ruangan yang luas, dengan dimainkan oleh 2 sampain 6 orang pemain dengan usia 3 sampai 6 tahun.

Ada juga permainan tradisional dari Jakarta bernama Ular naga, Yogyakarta Ancak-Ancak Alis, Jawa Timur Sledor, Bali Curik-Curik, Madura Ndor-Salendor, dan Palopo Sulawesi Selatan toko-toko dian. Pada alat permainan tidak ada alat permainan khusu tetapi menggunakan syair lagu, yakni: Syair lagu Ular Naga:

"Ular naga panjang bukan kepalang. Berjalan-jalan selalu riang gembira, umpannya lezat itulah yang dicari, inilah dia yang terbelakang"

Dan syair lagu oray-orayan yakni:

"Oray=orayan luar leor ka sawah....,

Tong ka sawah parena keur sedeng beukah.

Oray-orayan luar leor ka kebon....,

Tong ka kebon aya barudak keur ngangon.

Mending ge mandi di leuwi rea nu mandi

Saha nu mandi, nu mandina pendeuri...

Oray-orayan

Oray naon

Oray bungka

bungka naon

bungka laut

laut naon

laut dipa

dia naon

dipanderi ri...ri..rj..masuk ke terowongan".

Dan tempat bermain: di halaman, di lapangan, atau tempat yang agak luas kurang lebih 8x8meter, dengan jumlah pemain antara 7 sampai 20 orang, dengan usia pemain 3 sampai 6 tahun.

Kemudian permaian tradisional lainnya adalah yakni permainan Gebokan (umum), Jawa Tengah Ganepo, Sumatera Barat Lempar Kasti,dan Jawa Barat dan Banten Boy-Boyan. 
Alat permainan ini yakni:

1) Menggunakan sebuah bola tenis bekas,

2) Menggunakan bebeapa keping pecahan genting (talawengkar Sunda) antara 8 atau 10 buah yang besarnya kira-kira sebesar atau selebar telapak tangan anak-anak. Tempat berman yakni di luar ruang yang luas. Adapun pemain jumlahnya harus genap 10 orang dengan usia antara 4 sampai 6 tahun. Tempat permainan di luar ruangan yang luas. Jumlah pemain harus genap dan minimal 10 orang dengan usia 4 sampai 6 tahun.

Aturan mainnya adalah:

1) Anak yang kalah dalam undian akan menjadi penjaga,

2) Penjaga selanjutnya adalah anak yang ketahuan dan anak yang sedang berjaga mampu menyusun piramida pecahan genting,

3) Penjaga akan menjadi penjaga terus, apabila piramida berhasil dirobohkan oleh pemain yang lain.

Cara bermain adalah

1) Pada tahap persiapan:

(1) Mempersiapkan tempat,

(2) Mempersiapkan pemain,

(3) Membuat / membagi kelompok, dan

(4) Mengatur posisi pemain.

2) Pada tahap Pelaksanaan, adalah:

(1) Di permainan ini biasanya menggunakan pecahanan genteng atau batu-batu ceper yang disusun ke atas sehingga berbentuk menara dan kemudian pemain akan menjatuhkan (melempar) susunan itu dari jarak jauh dengan bola kasti,

(2) Jika susunan itu terjatuh maka lawan harus menyusun kembali pecahan genteng kemudian mengambil bola kasti dan melempar bola kasti ke arah pemain,

(3) Kemenangan ditandai dengan berdirinya menara pecahan genteng dan salah satu pemain terkena lemparan bola kasti (badan atau anggota badan kecuali kepala).

Adapun aspek yang dikembangkan adalah:

1) Aspek Moral dan Agama, yaitu selalu berdoa sebelum dan sesudah melakukan kegiatan dengan sikap yang benar, menghargai teman 
dan tidak memaksakan kehendak menolong teman.

2) Aspek Fisik, berlari dengan stabil berjalan dengan berbagai variasi, melompat, menangkap dan melempar bola dengan jarak 3-4 meter membedakan permukaan bola dan genting melalui perabaan,

3) Aspek Bahasa, berbicara lancar dengan menggunakan kalimat lancar, mengerti dan dapat melaksanakan lebih dari 3 perintah, memperkaya kosa kata, memecahkan masalah dengan dialog,

4) Aspek Kognitif, mengelompokkan benda yang sama dan sejenis, membedakan besar-kecil, berat ringan, menyebutkan 7 bentuk (lingkaran, bejur sangkar, segitiga, segi panjang, segi enam, belah ketupat dan trapesium), dan

5) Aspek Sosial -Emosional, bermain bersama dan bergantian menggunakan alat mainan, menunjukkan ekspresi wajar saat senang, kecewa dan marah, tertib menggunakan alat/benda sesuai dengan fungsinya, mengembalikan alat/ benda pada tempatnya semula, sabar menunggu giliran dan terbiasa antri, mengerti aturan main, mengerti akibat jika melanggar aturan, memiliki kebiasaan teratur, dapat memecahkan masalah sederhana, mengetahui hak dan kewajiban. ${ }^{35}$

\section{PERMAINAN DAN BENTUK PERMAINAN TRADISIONAL TUTU KALI KU MA ...MA... MBOJO - BIMA}

Permainan tradisional Mbojo-Bima ada beberapa yakni ada tutu kali ku ma..ma.. (Main hitung tangan yang dihitung dengan sebutan tutu kali ku ma..ma.. (binatang tanah yang kecil yang menyusup ke tanah kalau lagi musim kemarau bentuknya bulat kecil), mpa'a kaneke (Main kelereng), oro wele (bermain layang-layang), mpa ndeu aka mbere nente kapati kalo (mandi di sungai pada saat banjir, mpa'a ndeu aka ura mba mbua (mandi di hujan), lao mpa'a bedi o'o (bermain senjata dari bantu), mpa'a fenti (bermain pentil), mpa'a ngopa (bermain engkleng) dan masih banyak permainan tradisional Mbojo-Bima lainnya. Semuanya memiliki ciri keasyikan serta keunikan masing-masing sehingga anak-anak menyukai permainan tersebut.

${ }^{35}$ Ibid, hal. 16

Vol. 1, Nomor 1, Maret 2019 
Permainan tutu kali ku ma..ma..sendiri diilhami dari binatang tanah yang kecil yang menyusup ke tanah kalau lagi musim kemarau bentuknya bulat kecil, yang jika kita tarik keluar menggunakan lidi atau kayu kecil maka dia akan semakin menyusup ke tanah. Tanah yang didiami oleh binatang ini adalah tanah yang sudah berdebu yang ada dibawa wombo (kolom rumah panggung masyarakat Mbojo-Bima), sedangkan tanah yang mengental tidak didiami oleh binatang ini. Semakin berdebu tanahnya maka semakin banyak kali ku ma yang mendiami. Semakin di tarik ke luar maka semakin menyusup masuk ke dalam tanah, dengan melihat gerak-gerik binatang inilah anak-anak memiliki daya tarik dan keasyikan tersendiri terhadap binatang kali ku ma sendiri. Jika anak-anak bermain bersama-sama dengan temannya di wombo ((kolom rumah panggung masyarakat Mbojo-Bima), maka mereka pasti akan bermain mencari kali ku ma, semakin dicari maka kali ku ma nya semakin lari menyusut ke dalam tanah yang berdebu, dan ini membuat anak semakin senang dan gembira.

Sehingga ketika masuk pada wilayah sekolah terutama sekolah taman kanak-kanak maka anak-anak akan bermain tutu kali ku ma...ma.. dengan gembira. Dan jika disekolah maka mereka akan bermain scara kolektif dengan semua duduk melingkar lalu mereka mengepal tangannya seperti orang mau tinju, lalu memainkan permainan itu dengan mengepalkan kearah temannya. Tangan temannya disusun keatas lalu ditumbuk dengan tangan mereka sambil bernyanyi sebagai berikut:

Tutu kali ku ma...ma.......

Sa anggonggo wa'i le le..leu.....

La Jami mpako ka dui ma mpeke

Ka pela sara goa gopa ina na'e gepu.....

Wio wao salaja wao

Kido kado salaja kodo

Ka pela sara ngoa gopa ina nae gepu ${ }^{36}$

Lalu telapak tangan disusun kemudian ketua kelompok memilih mengambil tangan untuk dicubit atau kuping sambil diangkat keatas setinggi tingginya sehingga akan sakit sekali dengan mengatakan kata-kata:

${ }^{36}$ Syair lagu Bima: Tutu kali ku ma..ma.. , Yang diakses dari: http://ompundaru.wordpress. com/2008/11/28

Jurnal Pelang̉i Jurnal pemikiran dan penelitian pendidkan Islam anak Usia Dini 
Waura ngahamu.....

Lalu dijawab: wauraa.......

Ngaha kai uta au?????????

Ngaha kai uta karamba

Lalu sekali lai ketua kelompok bertanya dengan mencubit lebih keras

Ngaha ka uta au???????????

Ngaha kai uta kahoro ma roci hori

Setelah itu ketua kelompok dengan cepat melepas tangannya yang mencupit tangan atau kuping terserah yang dipilih oleh ketua kelompok permainan tersebut.

Setelah itu dilakukan permainan yakni bersembunyi di tempat-tempat yang dianggap tidak mudah diketahui oleh penjaga permainan tadi, dengan mengatakan:

Wauraa......????

Waura........????

Waura.......?????

Waura.......?????

Lalu dijawab: Wauraa

Lalu dilihatlah oleh ketua kelompok permainan dan mengatakan:

Akaku waura eda mba nahu re

Lalu itu aja yang dilakukan hingga selesai permainan dan didapatlan siapa yang akan dihukum. Hukumannya adalah apakah itu dicubit, dipukul telapak tangannya. Maka selesailah sudah permainan tutu kali ku ma..ma..

Dan ketika mereka sudah pulang sekolah pun mereka bisa melakukan permainan ini dirumah, serta sepulang mengaji dari guru ngaji yang dantar oleh orang tua dan saudara mereka maka mereka akan bermain tutu kali ku ma..ma.. ini dengan teman-teman.

Hal ini diungkapkan oleh Carron dan Jan, bahwa bermain merupakan suatu sarana yang memungkinkan anak berkembang secara optimal. Bermain dapat mempengaruhi semua perkembangan dengan memberikan kesempatan kepada anak untuk belajar tentang dirinya sendiri, orang lain dan lingkungan. Bermain memberikan kebebasan kepada anak untuk berimajinasi, bereksplorasi, dan menciptakan sesuatu. ${ }^{37}$ Bruner dalam

\footnotetext{
${ }^{37}$ Putri Admi Perdani. Peningkatan Ketrampilan Sosial Anak Melalui Permainan Tradisional. Jurnal Pendidikan Usia Dini. Volume 8 Edisi I, April, 2014, hal 132, dikutip dari: Carron \& Jan, 1999: 21
} 
Hurlock, bermain adalah kegiatan yang serius dan merupakan kegiatan pokok dalam masa kanak-kanak. ${ }^{38}$ Lalu Mayesky juga mengatakan bagi anak-anak bermain adalah hal yang mereka lakukan sepanjang hari karena hidupnya adalah bermain. ${ }^{39}$ Lalu Ki Hajar Dewantara pun mengatakan bahwa bermain merupakan kegiatan keseharian setiap anak. ${ }^{40}$ Jedjasaputra juga mengatakan bahwa bermain adalah dunia kerja anak usia prasekolah dan menjadi hak setiap anak untuk bermain, tanpa dibatasi usia. ${ }^{41}$ Berdasarkan pengertian diatas, maka dapat disimpulkan bahwa bermain pada masa kanak-kanak merupakan kegiatan keseharian sebagai dasar pembelajaran yang dilakukan dengan serius oleh setiap anak secara alamiah mengenai diri sendiri dan lingkungannya dan pekerjaan anak yang menunjukkan tingkah laku yang menyenangkan, dinamis, aktif, dan konstruktif. ${ }^{42}$

Kemudian Agung Nugroho dalam skripsinya yang berjudul permainan tradisional anak-anak sebagai sumber ide dalam penciptaan karya seni grafis, mengungkapkan bahwa permainan tradisional anak adalah seiring lahirnya kebudayaan. ${ }^{43}$ Banyak pendapat yang mengatakan bahwa permainan merupakan warisan nenek moyang kita, warisan dari pada leluhur kita. Sehingga dengan melestarikan sebagai kebudayaan nenek moyang kita. Namun pewarisan itu sendiri selalu mengalami perubahan sesuai dengan perkembangan zaman dan perkembangan kebudayaan. ${ }^{44}$ Pendapat diatas dapat ditarik kesimpulan bahwa semua permainan tradisional itu perlu dilestarikan, karena dilihat dari makna yang terkandung.

Pada dasarnya permainan tradisional sarat dengan nilai-nilai luhur yang dapat dijadkan bekal dan pedoman hidup bagi anak yang memainkannya. Nilai-nilai yang terkandung dalam permainan tradisional sangat penting dalam pembentukan kepribadian anak, yang hal ini sangat

\footnotetext{
${ }^{38}$ Ibid, hal 132, Dikutip dari: Bruner Dalam Hurlock, 1980: 121

${ }^{39}$ Ibid, hal 132, Dikutip dari: Mayesky, 1990: 197

${ }^{40}$ Ibid, hal. 132, Dikutip dari: Ki Hajar Dewantara, 1997: 243

${ }^{41}$ Ibid, hal. 132, Dikutip dari: Tedjasaputra, 2001: xvi

${ }^{42}$ Ibid, hal 132

${ }^{43}$ Agung Nugroho. Permainan Tradisional anak-anak sebagai sumber ide dalam pencitaan Karya Seni Grafis. Skripsi. Jurusan Seni Rupa Murni, Fakultas Sastra dan Seni Rupa. Universitas Negeri Sebelah Maret . Surakarta. 2005, hal. 28

${ }^{44}$ Ibid, hal 29
}

Jurnal Pelang̉i Jurnal pemikiran dan penelitian pendidkan Islam anak Usia Dini 
penting pula untuk menangkal datangnya pengaruh-pengaruh asing yang masuk, terutama dari media televisi dan perkembangan teknologi. Dengan bermain permainan tradisional terkadang anak dilatih untuk mengerti sikap mengalah, sosial, berteman, kegotong royongan. Tentu saja ini berlawanan dengan berbagai jenis permainan. ${ }^{45}$

\section{RELEVANSI PERMAINANTRADISIONAL MBOJO-BIMATUTU KALI KU MA..MA...UNTUK MENSTUMULASI KETRAMPILAN ANAK USIA DINI}

Permainan tutu kali ku ma...ma.. memiliki hubungan yang kuat dengan pertumbuhan dan perkembangan anak usia dini khususnya. Dengan adanya permainan-permainan seperti ini maka akan membantu stimulus anak usia dini. Sehingga cakrawala berfikirnya menjadi sangat luas, maju dan kreatif dan yang terpenting anak-anak akan merasa senang, gembira dan bahagai tanpa ada beban sebagai seorang anak. Anak akan lebih terbuka bermain bersama teman-temannya dan akan menambah keakraban antara anak yang satu dengan yang lainnya. Apalagi bila anak itu sudah pulang ke rumahnya masing-masing maka hubungan sosial masyarakat dengan teman-teman sebayangnya tidak terputus begitu saja. Biasanya anak-anak akan selalu mengingat apa yang dilakukan olehnya ketika di sekolah taman kanak-kanak bersama dengan teman-temannya, lalu jika rumah mereka berdekatan maka anak-anak akan mendatangi rumah temannya untuk bermain lagi, mengulangi lagi permainan yang telah dilakukan disekolah tadi. Sehingga hubungan sosialnya tidak hanya dengan teman-teman sebaya nya tetapi dengan kakak-kakak temannya, adik-adik temannya, orang tua temannya, dan juga tetangga-tetangga temannya. Sehingga hubungan sosial kemanysrakatan itu sudah terpupuk dan terbina mulai dari usia dini ini. Ketika mereka naik ke anak-anak, remaja dan dewasa pelajaran dan pengalaman yang telah dilaluinya semasa kecil akan berpengaruh terhadap kehidupan selanjutnya kelak.

Anak-anak sudah terbiasa bertemu, bertatap muka, bergaul dan berbicara dengan semua jenis umur, sehingga rasa takut, canggung

\footnotetext{
${ }^{45} \mathrm{Ibid}$, hal 40
} 
dan minder itu sudah diminimalisir dari usia dini karena anak sudah pernah bertemu dengan banyak orang sebelumnya. Pertumbuhan dan perkembangan anak akan berpengaruh ke tingkat remaja dewasa akibat lingkungan dan alam sekitar yang mempengaruhinya. Seefeldt dan Barbour mengatakan bahwa ketrampilan sosial anak meliputi: ketrampilan komunikasi, berbagi (sharing), bekerja sama, dan berpartisipasi dalam kelompok masyarakat. Anak-anak yang mempunya kesadaran diri yang kuat, siap untuk belajar hidup bersama dengan orang lain. Kemampuan berkomunikasi adalah perilau-perilaku yang dipelajarari untuk digunakan individu dalam situasi-situasi interpersonal untuk memperoleh dan memelihara penguatan dari lingkungan. Ketrampilan sosial diperoleh melalui proses belajar, bak belajar dari orang tua sebagai figur yang paling dekat dengan anak maupun belajar dari teman sebaya dan lingkungan masyarakat. ${ }^{46}$ Lalu Walker Rosenbeng mengatakan pula bahwa menjelaskan ketrampilan sosial secara umum respon-respon dan ketrampilan yang memberikan seorang individu untuk mempertanahnkan hubungan positif dengan orang lain. Penerimaan teman-teman sebayanya, pengusaan ruang kelas yang baik dan memberikan individu untuk mengatasi secara efektif dan bisa diadaptasi dengan lingkungan sosial. ${ }^{47}$ Pendapat diatas disimpulkan bahwa ketrampilan sosial adalah kemampuan berkomunikasi, bekerja-sama, berbagi, berpartisipasi, dan beradaptasi (bentuk simpati, empati, mampu memecahkan masalah serta disiplin sesuai dengan peraturan dan norma yang berlaku. Lalu Elksnin dan Elksnin mengidentifikasikan ciri-ciri ketrampilan sosial, meliputi: perilaku interpersonal, perilaku yang berhubungan dengan diri sendiri, perilaku yang berhubungan dengan kesuksesan akademis, perilku yang berhubungan dengan peerimaan teman sebaya (peer acceptace), dan ketrampilan komunikasi.

Sedangkan interpersonal adalah perilaku yang menyangkut ketrampilan yang digunakan selama melakukan interaksi sosial yang disebut juga ketrampilan menjalin persahabatan, misalnya memperkenalkan diri, menawarkan bantuan dan memberikan atau menerima pujian. Ketrampilanini memungkinkan hubungan dengan usia danjenis kelamin.

\footnotetext{
${ }^{46}$ Ibid, hal 126-127, dikutip dari: Seefeldt \& Barbour, 1994: 57-59

${ }^{47}$ Ibid, hal. 127
} 
Perilaku yang berhubungan dengan diri sendiri merupakan ketrampilan mengatur diri sendiri dalam situasi sosial, dengan kemampuan ini anak dapat memperkirakan kejadian-kejadian yang mungkin akan terjadi dan dampak perilakunya pada situasi sosial tertentu. Perilaku yang berhubungan dengan kesuksesan akademis, meliputi: perilaku atau ketrampilan sosial yang dapat mendukung prestasi belajar di sekolah. Perilaku yang berhubungan dengan penerimaan teman sebaya (peer ecceptace). ${ }^{48}$

Jadi kesimpulannya bahwa ketrampilan sosial anak meliputi: ketrampilan komunikasi, berbagi (sharing), bekerja sama, dan berpartisipasi dalam kelompok masyarakat. Anak-anak yang mempunya kesadaran diri yang kuat, siap untuk belajar hidup bersama dengan orang lain. Kemampuan berkomunikasi adalah perilau-perilaku yang dipelajarari untuk digunakan individu dalam situasi-situasi interpersonal untuk memperoleh dan memelihara penguatan dari lingkungan. Ketrampilan sosial diperoleh melalui proses belajar, bak belajar dari orang tua sebagai figur yang paling dekat dengan anak maupun belajar dari teman sebaya dan lingkungan masyarakat

\section{E. KESIMPULAN}

Kesimpulan yang dapat diambil dalam artikel ini adalah bahwa bentuk permainan trandisonal Mbojo-Bima Tutu Kali Ku ma..ma.. adalah

Tutu kali ku ma...ma.......

Sa anggonggo wa'i le le..leu.....

La Jami mpako ka dui ma mpeke

Ka pela sara goa gopa ina na'e gepu.....

Wio wao salaja wao

Kido kado salaja kodo

Ka pela sara ngoa gopa ina nae gepu

Lalu telapak tangan disusun kemudian ketua kelompok memilih mengambil tangan untuk dicubit atau kuping sambil diangkat keatas setinggi tingginya sehingga akan sakit sekali dengan mengatakan kata-kata:

Waura ngahamu.....

Lalu dijawab: wauraa.......

${ }^{48}$ Ibid, hal 130-132 
Ngaha kai uta au?????????

Ngaha kai uta karamba

Lalu sekali lai ketua kelompok bertanya dengan mencubit lebih keras

Ngaha ka uta au???????????

Ngaha kai uta kahoro ma roci hori

Setelah itu ketua kelompok dengan cepat melepas tangannya yang mencupit tangan atau kuping terserah yang dipilih oleh ketua kelompok permainan tersebut.

Setelah itu dilakukan permainan yakni bersembunyi di tempat-tempat yang dianggap tidak mudah diketahui oleh penjaga permainan tadi, dengan mengatakan:

Wauraa......????

Waura........?????

Waura.......?????

Waura.......????

Lalu dijawab: Wauraa

Lalu dilihatlah oleh ketua kelompok permainan dan mengatakan:

Akaku waura eda mba nahu re

Lalu itu aja yang dilakukan hingga selesai permainan dan didapatlan siapa yang akan dihukum. Hukumannya adalah apakah itu dicubit, dipukul telapak tangannya. Maka selesailah sudah permainan tutu kali ku ma..ma...

Permainan tradisional anak merupakan lahir dari kebudayaan. permainan merupakan warisan nenek moyang, warisan dari pada leluhur kita. Sehingga dengan melestarikan sebagai kebudayaan nenek moyang kita. Namun pewarisan itu sendiri selalu mengalami perubahan sesuai dengan perkembangan zaman dan perkembangan kebudayaan.

Relevansi permainan tradisional Mojo-Bima Tutu Kali ku ma..ma.. untuk menstimulasi ketrampilan anak usia dini adalah permainan tutu kali ku ma...ma.. memiliki hubungan yang kuat dengan pertumbuhan dan perkembangan anak usia dini khususnya. Dengan adanya permainanpermainan seperti ini maka akan membantu stimulus anak usia dini. Sehingga cakrawala berfikirnya menjadi sangat luas, maju dan kreatif dan yang terpenting anak-anak akan merasa senang, gembira dan bahagai tanpa ada beban sebagai seorang anak. Anak akan lebih terbuka bermain bersama teman-temannya dan akan menambah keakraban antara

Jurnal Pelang̉i Jurnal pemikiran dan penelitian pendidkan Islam anak Usia Dini 
anak yang satu dengan yang lainnya. Apalagi bila anak itu sudah pulang ke rumahnya masing-masing maka hubungan sosial masyarakat dengan teman-teman sebayangnya tidak terputus begitu saja. Biasanya anakanak akan selalu mengingat apa yang dilakukan olehnya ketika di sekolah taman kanak-kanak bersama dengan teman-temannya, lalu jika rumah mereka berdekatan maka anak-anak akan mendatangi rumah temannya untuk bermain lagi, mengulangi lagi permainan yang telah dilakukan disekolah tadi. Sehingga hubungan sosialnya tidak hanya dengan temanteman sebaya nya tetapi dengan kakak-kakak temannya, adik-adik temannya, orang tua temannya, dan juga tetangga-tetangga temannya. Sehingga hubungan sosial kemanysrakatan itu sudah terpupuk dan terbina mulai dari usia dini ini. Ketika mereka naik ke anak-anak, remaja dan dewasa pelajaran dan pengalaman yang telah dilaluinya semasa kecil akan berpengaruh terhadap kehidupan selanjutnya kelak.akan

\section{REFERENSI}

Aulio Rohmawati. Stimulasi Ketrampilan sosial anak Ditinjau Dari Satuan Pendidikan Anak Usia Dini. Skripsi. Program Studi Pendidikan Guru Pendidikan Anak Usia Dini, Fakultas Ilmu Pendidikan, Universitas Negeri Semarang, 2016, ., Dikutip dari: Anderson, et.al. 2003: 32

Agung Nugroho. Permainan Tradisional anak-anak sebagai sumber ide dalam pencitaan Karya Seni Grafis. Skripsi. Jurusan Seni Rupa Murni, Fakultas Sastra dan Seni Rupa. Universitas Negeri Sebelah Maret. Surakarta. 2005, hal 126-127, dikutip dari: Seefeldt \& Barbour, 1994: 57-59

Betty Yulia Wulansari. Pelestarian Seni Budaya dan Permaian Tradisional Melalui Tema Kearifan Lokal Dalam Kurikulum Pendidikan Anak Usia Dini. Jurnal Ilmiah Pendidikan Pra-Sekolah dan Sekolah Awal. Indria. e-ISSN 2524 - 004X JL II (I). Universitas Muhammadiyah Ponorogo, 2017.

,., Dikutip dari: Agung Nugroho, 2005

Gian Prantoro. Pengaruh Penggunaan Permainan Tradisional Bakiak dan Engklek Terhadap Peningkatan Ketrampilan Sosial Anak Usia Dini. Skripsi. Pada Program Studi Teknologi Pendidikan, Jurusan 
Kurikulum dan Teknologi Pendidikan, Fakultas Ilmu Pendidikan, Universitas Negeri Yogyakarta, 2015, hal. 27, dikutip dari: Sukirman Dharmamulya, 2004: 35 hal 27, Dikutip dari Sukirman, hal 2004: 37, 123, 139 hal 2. Dikutip dari: Kompasiana, 2016.

Heru Subagiyo. Permainan Tradisional Sebagai Media Pembelajaran Anak. Jurnal.

Konsep Permainan. Hal 1, Dikutip dari: Hans Daeng, 2009: 17 , hal 1, Dikutip dari: Andang Ismail, 2009: 26

Permainan Anak dan Aktivitas Ritmik. Modul 4.

Ni Nyoman Seriati dan Nur Hayati, Permainan Tradisional Jawa Gerak dan Lagu Untuk Menstimulasi Ketrampilan Sosial Anak Usia Dini. Artikel. Pendidkan Seni Tari PGPAUD, HAL. 1, Dikutip dari: Lawhon, 2000 Dikutip dari: Ayrizi, Izzaty dan Setiawati, 2004

Dikutip dari: Seriati, 2010

.,Dikutip dari: Sujiono, 2005

, Dikutip dari: Plato, dkk, dalam Sujiono, 2005

, Dikutip dari: Suyanto, 2005

, Dikutip dari: Curtis, 1988

.,Dikutip dari: Kelly dalam Ramdhani, 1991

..,Dikutip dari: Morgan dalam Cartledge dan Milburn, 1995

,Dikutip dari: Curtis, 1988, Brewer 2007, dan Depdiknas 2002. .,Dikutip dari: Yunus, 1981

Syair lagu Bima: Tutu kali ku ma..ma.. , Yang diakses dari: http:// ompundaru.wordpress.com/2008/11/28

Putri Admi Perdani. Peningkatan Ketrampilan Sosial Anak Melalui Permainan Tradisional.Jurnal Pendidikan Usia Dini. Volume 8 Edisi I, April, 2014, hal 132, dikutip dari: Carron \& Jan, 1999: 21

Dikutip dari: Bruner Dalam Hurlock, 1980: 121

Dikutip dari: Mayesky, 1990: 197

Dikutip dari: Ki Hajar Dewantara, 1997: 243

Dikutip dari: Tedjasaputra, 2001: xvi

Jurnal Pelangi Jurnal pemikiran dan penelitian pendidkan Islam anak Usia Dini 